\title{
In vitro antibacterial activity and essential oil composition of Litsea petiolata Hook. f. leaves
}

\author{
Patumporn Thongthip ${ }^{1}$, Piyamas Atiphasaworn ${ }^{1}$, Sakon Monggoot ${ }^{1}$, Acharavadee Pansanit ${ }^{1,2 *}$, Patcharee Pripdeevech ${ }^{1,2^{*}}$ \\ ${ }^{1}$ School of Science, Mae Fah Luang University, Chiang Rai 57100, Thailand. \\ ${ }^{2}$ Center of Chemical Innovation for Sustainability (CCIS), Mae Fah Luang University, Chiang Rai 57100, Thailand.
}

\section{ARTICLE INFO}

Article history:

Received on: 16/03/2017

Accepted on: 20/07/2017

Available online: 30/09/2017

\section{Key words:}

Litsea petiolata (Hook f), essential oil, antibacterial, composition, GC-MS.

\begin{abstract}
Essential oil of Litsea petiolata (Hook f) was extracted from their leaves collecting from Chiang Rai province, Northern Thailand. Hydrodistillation technique with Clevenger system was performed to extract L. petiolata essential oil. The essential oil composition was further analyzed by gas chromatographic-mass spectrometric technique. A total of 74 volatile constituents were identified. Representing $96.94 \%$ of the oil with 2-ketonesare the key compound group. The major identified volatile components were 2-undecanone (79.52\%), 12-tridecen2-one $(6.26 \%)$ and 2 -nonanone $(2.46 \%)$, respectively. The essential oil of L. petiolata (Hook f) leaves showed good antibacterial activity against tested Gram-positive and Gram-negative human pathogenic bacteria including Bacillus cereus ATCC 11778, B. subtilis TISTR 008, Staphylococcus aureus ATCC 25923, S. epidermidis ATCC 12228, S. agalactiae DMST 17129, Escherichia coli ATCC 25922, Salmonella typhimurium ATCC 13311, Vibrio cholerae DMST 2873 and V. parahaemolyticus DMST 21243. The zone of inhibition was obtained from $9.54 \pm 1.24$ to $18.07 \pm 2.19 \mathrm{~mm}$. The minimum inhibitory concentration (MIC) values were within the antibacterial activity range and varied between 31.25 and $500 \mu \mathrm{g} / \mathrm{mL}$. The essential oil of $L$. petiolata (Hook f) leaves showed maximum antibacterial activity against $S$. aureus ATCC 25923 and E. coli ATCC 25922 . This study indicates that $L$. petiolata (Hook f) leaf oil could be employed as a natural medicinal application in antibacterial drugs.
\end{abstract}

\section{INTRODUCTION}

Treatments of human health and welfare have been increased continuously according to numbers of infectious diseases. They are the major problems for immense morbidity and mortality in all parts of the world especially developing countries (Memish et al., 2003). The usual infectious diseases including incidences of nosocomial and opportunistic infections have also expanded intensely. Moreover, new or drug resistant pathogens are increasing and developing day by day causing from number of infection diseases. Hospitalized patients with immunodeficiency may take high risk of severe and invasive infections. In order to improve the problem, new or novel antimicrobial agents are urgently needed.

\footnotetext{
* Corresponding Author

E-mail: acharavadee.pan@mfu.ac.th,

E-mail: patcharee.pri@mfu.ac.th
}

Plants, especially in developing countries, are considered as an important resource of various drugs to prevent diseases due to various biodiversites. They have been employed in classical remedies for curing of common illnesses by approximately $60-80 \%$ of the world's population (Zhang, 2004). Essential oils are aromatic viscous liquids produced from aromatic plants containing a group of secondary metabolites mainly terpenoids with aromatic properties (Stefanakis et al., 2013). They are used intensively as antimicrobial, antivirals, and antioxidants (Pandey et al., 2014). Essential oils are also considered to be safe ingredients for using as antibacterial additives (Tian et al., 2014). According to many reports on the antimicrobial and antioxidant capacity, essential oil has been selected as natural antimicrobial and antioxidant agents continuously (Hossain et al., 2014; Jallali et al., 2014). Litsea petiolata (Hook f) (family Lauraceae) is known in Thai as Tummung. It is a medium-sized trees intensively cultivated in the Southern and Northeastern parts of Thailand. 
Their leaves possess individually unique odor. No previous studies report the antibacterial properties of L. petiolata (Hook f) leaf oil while the related species such as L. japonica leaf extract presented anti-inflammatory and anti-oxidative activities (Yoon et al., 2010). In addition to being flavoring foods, methanol extract of L. petiolata (Hook f) can also act as antioxidant agent reported by Suksamerkun et al. (2013).

In the present work, the essential oil of $L$. petiolata (Hook f) leaves from Thailand was extracted prior their chemical composition was investigated by gas-chromatographic-mass spectrometric analyses. Their antibacterial activities against tested pathogenic bacteria were also evaluated.

\section{EXPERIMENTAL}

Plant material

Fresh leaves of L. petiolata (Hook f) was collected in Chiang Rai province, Northern Thailand (99 87'10" E, $20^{\circ} 33^{\prime} 06^{\prime \prime} \mathrm{N}$ ) between 5:00 and 6:00 pm, in the first week on August 2016. Three year old L. petiolata was identified and deposited at the Mae Fah Luang University Botanical Garden, Chiang Rai, Thailand as voucher herbarium specimen of MFLU No. 10004.

\section{Essential oil extraction}

The extraction of $L$. petiolata (Hook f) leaf oil was obtained from $250 \mathrm{~g}$ fresh plants by hydro-distillation using Clevenger system, during $4 \mathrm{~h}$. Excess water retained in crude essential oil was removed by using anhydrous sodium sulphate. Pure essential oil was collected in sealed vial. The essential oil was dissolved in dichloromethane $(1 / 100 \mathrm{v} / \mathrm{v})$ prior injecting to gas chromatographic-mass spectrometric tool.

\section{Chromatography conditions}

The volatile constituents of L. petiolata (Hook f) leaf oil was investigated using a Hewlett Packard model HP6890 gas chromatograph (Agilent Technologies, Palo Alto, CA, USA) with an HP-5MS (5\% phenylpolymethylsiloxane) capillary column (30 $\mathrm{m} \times 0.25 \mathrm{~mm}$ i.d., film thickness $0.25 \mu \mathrm{m}$; Agilent Technologies, USA) and interfaced to an HP model 5973 mass selective detector operating in electron impact mode with $70 \mathrm{eV}$. Injector and detector temperatures were set at $250{ }^{\circ} \mathrm{C}$ and $280{ }^{\circ} \mathrm{C}$, respectively. One micro-liter of diluted essential oil was injected and their chemical composition was separated in the column held initially at $60{ }^{\circ} \mathrm{C}$ and then raised up to $240{ }^{\circ} \mathrm{C}$ with a rate of $3{ }^{\circ} \mathrm{C} / \mathrm{min}$. Helium, carrier gas, was used in this study with a flow rate of 1 $\mathrm{mL} / \mathrm{min}$.

The percentage peak area was calculated relative to total peak area of individual identified components. Identification of the volatile constituents was performed by comparing mass spectra with those of authentic reference compounds and retention indices to $\mathrm{C}_{7}-\mathrm{C}_{22} n$-alkanes, and using a comparison of the mass spectra of individual components with the reference mass spectra in the W8N08 and NIST08 databases, and literature (Adams, 2001).

\section{Bacterial pathogens}

Antibacterial activity tests of $L$. petiolata (Hook f) leaf oil were carried out against the Gram-positive bacteria including Bacillus cereus ATCC 11778, B. subtilis TISTR 008, Enterococcus faecalis ATCC 29212, Staphylococcus aureus ATCC 25923, S. epidermidis ATCC 12228 and S. agalactiae DMST 17129, and Gram-negative bacteria including Escherichia coli ATCC 25922, Klebsiella pneumoniae ATCC 700603,Proteus mirabilis DMST 8212, Pseudomonas aeruginosa ATCC 27853, Salmonella typhi DMST 22842, S. typhimurium ATCC 13311, Shigella flexneri DMST 4423, Vibrio cholerae DMST 2873 and V. parahaemolyticus DMST 21243. These bacteria with ATCC and TISTR code were obtained from Department of Medical Science, Ministry of Health Bangkok and Thailand Institute of Scientific and Technological Research, Pathum Thani, Thailand while DMST code was obtained from Culture Collection for Medical Microorganisms, Department of Medical Sciences, Thailand.

\section{Antibacterial activity}

Screening of antibacterial activities of L. petiolata (Hook f) leaf oil was performed by the disk diffusion method (Mar and Pripdeevech, 2014). It was done using an $24 \mathrm{~h}$ culture at $37{ }^{\circ} \mathrm{C}$ in $10 \mathrm{~mL}$ tryptic soy broth medium (BIO BASIC INC., USA). All bacteria were cultured to nearly $105 \mathrm{CFU} / \mathrm{mL}$ in solution of sterile saline. Culture suspension $(300 \mathrm{~mL})$ were spread on a sterile plates containing Mueller-Hinton agar. The essential oil was dissolved in dichloromethane to obtain various concentrations; 1000, 500, 250, $125,62.50,31.25,15.627 .81$ and $3.91 \mu \mathrm{g} / \mathrm{mL}$. A sterilized 6-mm of paper disc (Whatman ${ }^{\mathrm{TM}}$, USA) moistened with $30 \mu \mathrm{L}$ of sample was placed on the agar surface. A standard disc containing penicillin was used as reference control. All plates were sealed with sterile parafilm to prevent evaporation of the test samples. The plates were incubated at $37^{\circ} \mathrm{C}$ for $24 \mathrm{~h}$. After the incubation period, the zone of inhibition and minimum inhibition concentration (MIC) was measured. Screening of antibacterial activity was experimented in triplicate, and mean value was also determined.

\section{RESULTS AND DISCUSSION}

The essential oil $(10.89 \% \mathrm{w} / \mathrm{w})$ yield was obtained from $L$. petiolata (Hook f) leaves. The chemical composition of $L$. petiolata (Hook f) leaf oil obtained was investigated by GC-MS which allowed identification of about $96.94 \%$ of oil constituents (Table 1). The major components from L. petiolata (Hook f) leaf oil were 2-undecanone (79.52\%) , 12-tridecen-2-one (6.26\%) , 2nonanone $(2.46 \%)$ and $2 E, 6 Z$-farnesol $(1.67 \%)$ while transpulegol $(0.78 \%), 8$-nonene-2-one $(0.39 \%)$, abienol $(0.34 \%)$ and $2 E, 4 E$-decadienol $(0.22 \%)$ were considered as minor components. Pulpipat et al. (2011) also reported 2-undecanone, 2-nonanone and $2 E, 6 Z$-farnesol as the key volatile components of extract of $L$. petiolata (Hook $\mathrm{f}$ ) leaves obtained by using supercritical fluid carbon dioxide extraction method. 
Table 1: Chemical composition of L. petiolata (Hook f) leaf oil with the percentage of content obtained by hydrodistillation.

\begin{tabular}{|c|c|c|c|c|c|c|c|}
\hline No. & Compound & RI & $\%$ area & No. & Compound & RI & $\%$ area \\
\hline 1 & hexen-3-ol & 779 & 0.05 & 38 & epi-cubebol & 1494 & 0.05 \\
\hline 2 & 3Z-hexenol & 850 & 0.09 & 39 & $\beta$-bisabolene & 1505 & 0.09 \\
\hline 3 & 2Z-hexenol & 861 & 0.04 & 40 & 2E,4E-dodecadienal & 1517 & 0.09 \\
\hline 4 & tricyclene & 917 & 0.04 & 41 & citronellyl butanoate & 1529 & 0.08 \\
\hline 5 & artemisia triene & 924 & 0.04 & 42 & furopelargone $\mathrm{A}$ & 1537 & 0.05 \\
\hline 6 & benzaldehyde & 963 & 0.06 & 43 & 1,10 -decanediol & 1548 & 0.08 \\
\hline 7 & sabinene & 967 & 0.05 & 44 & geranyl butanoate & 1563 & 0.05 \\
\hline 8 & $\beta$-pinene & 971 & 0.11 & 45 & gleenol & 1584 & 0.07 \\
\hline 9 & trans-meta-mentha-2,8-diene & 979 & 0.04 & 46 & globulol & 1591 & 0.08 \\
\hline 10 & dehydroxy-trans-linalool oxide & 993 & 0.04 & 47 & epi-cedrol & 1618 & 0.12 \\
\hline 11 & $\delta$-2-carene & 997 & 0.05 & 48 & 2 -epi- $\alpha$ cedren-3-one & 1625 & 0.08 \\
\hline 12 & $\alpha$-phellandrene & 1003 & 0.05 & 49 & 2E-hexenyl phenyl acetate & 1636 & 0.04 \\
\hline 13 & $\alpha$-terpinene & 1014 & 0.06 & 50 & Z-amyl cinnamaldehyde & 1649 & 0.09 \\
\hline 14 & E-ethyl-2-methyl-2-pentenoate & 1017 & 0.07 & 51 & dihydro-eudesmol & 1661 & 0.09 \\
\hline 15 & Z- $\beta$-ocimene & 1033 & 0.04 & 52 & E-citronellyl tiglate & 1666 & 0.08 \\
\hline 16 & E- $\beta$-ocimene & 1044 & 0.04 & 53 & trans-methyl dihydro jasmonate & 1681 & 0.05 \\
\hline 17 & isobutyl acetoacetate & 1059 & 0.05 & 54 & 2E,6Z-farnesol & 1706 & 1.67 \\
\hline 18 & 8-nonene-2-one & 1070 & 0.39 & 55 & 2E,6E-farnesoic acid & 1818 & 0.04 \\
\hline 19 & 2-nonanone & 1081 & 2.46 & 56 & 7-hydroxy coumarin & 1837 & 0.08 \\
\hline 20 & terpineol & 1129 & 0.04 & 57 & hexadecanol & 1871 & 0.12 \\
\hline 21 & 3Z-hexenyl isobutanoate & 1143 & 0.12 & 58 & 5E,9Z-farnesyl acetone & 1884 & 0.11 \\
\hline 22 & $\delta$-terpineol & 1162 & 0.11 & 59 & 5E,9E-farnesyl acetone & 1905 & 0.16 \\
\hline 23 & 2-decanone & 1178 & 0.14 & 60 & carissone & 1926 & 0.08 \\
\hline 24 & trans-pulegol & 1211 & 0.78 & 61 & cembrene & 1937 & 0.08 \\
\hline 25 & 2-undecanone & 1297 & 79.52 & 62 & 3E-cembrene A & 1953 & 0.05 \\
\hline 26 & 2E,4E-decadienol & 1320 & 0.22 & 63 & geranyl benzoate & 1959 & 0.06 \\
\hline 27 & 4-hydroxybenzaldehyde & 1358 & 0.08 & 64 & sclarene & 1972 & 0.06 \\
\hline 28 & cyclosativene & 1366 & 0.07 & 65 & 7-hydroxy-4-methyl coumarin & 1978 & 0.09 \\
\hline 29 & linalool isobutanoate & 1373 & 0.08 & 66 & ethyl hexadecanoate & 1993 & 0.13 \\
\hline 30 & 2-dodecanone & 1383 & 0.07 & 67 & ethylene brassylate & 2010 & 0.04 \\
\hline 31 & longifolene & 1407 & 0.18 & 68 & juvibione & 2015 & 0.13 \\
\hline 32 & $\beta$-duprezianene & 1422 & 0.08 & 69 & canellal & 2047 & 0.06 \\
\hline 33 & cis- $\alpha$-ambrinol & 1439 & 0.09 & 70 & methyl linoleate & 2106 & 0.14 \\
\hline 34 & cis-cadina-1 (6), 4-diene & 1461 & 0.06 & 71 & methyl octadecanoate & 2123 & 0.11 \\
\hline 35 & cis-muurola-4 (14), 5-diene & 1465 & 0.08 & 72 & abienol & 2147 & 0.34 \\
\hline 36 & 12-tridecen-2-one & 1479 & 6.26 & 73 & incensole acetate & 2184 & 0.19 \\
\hline 37 & 2-tridecanone & 1485 & 0.08 & 74 & ethyl octadecanoate & 2194 & 0.18 \\
\hline
\end{tabular}

RI, linear temperature program retention index on DB-5 column.

However, content of minor components in this study were varied when compared to those found in Pulpipat et al. (2011) due to different extraction method, various ecological and biological conditions, as well as genetic factor. The results for inhibition zone diameter and MIC assay of L. petiolata (Hook f) leaf oil and penicillin against tested bacterial pathogens are shown in Table 2. The MIC values of $L$. petiolata (Hook f) leaf oil were in the ranges of $31.25-500 \mu \mathrm{g} / \mathrm{mL}$. The MIC values for Grampositive bacteria were $31.25-500 \mu \mathrm{g} / \mathrm{mL}$. The L. petiolata (Hook f) leaf oil exhibited inhibitory effect against $B$. cereus ATCC 11778, B. subtilis TISTR 008 and S. epidermidis ATCC 12228 at MIC of $125 \mu \mathrm{g} / \mathrm{mL}$. The MIC values of $L$. petiolata (Hook f) leaf oil against $S$. agalactiae DMST 17129 was higher than those of the other Gram-positive bacteria $(500 \mu \mathrm{g} / \mathrm{mL})$. The essential oil of $L$. petiolata (Hook f) leaves had bactericidal effect against some tested Gram-negative bacteria including E. coli ATCC 25922, S. typhimurium ATCC 13311, V. cholerae DMST 2873 and $V$. parahaemolyticus DMST 21243. Among the tested Gram-negative bacteria, the MIC values of $V$. cholerae DMST 2873 were higher than those of others $(\mathrm{MIC}=250 \mu \mathrm{g} / \mathrm{mL}$ ). In addition, $S$. aureus ATCC 25923 and E. coli ATCC 25922 showed more sensitivity to essential oil of $L$. petiolata (Hook f) leaves and the oil had antibacterial activities on both bacterial pathogens
(MIC $=31.25 \mu \mathrm{g} / \mathrm{mL}$ ). The complex mixtures of various volatile components in the essential oil of L. petiolata (Hook f) leaves may afford multiple mechanisms for potential antibacterial activity. The major components of $L$. petiolata (Hook f) leaf oil were considered to play an important role in the antibacterial activity, while the minor volatile constituents were also detected to result in synergistic outcomes ( $\mathrm{Li}$ et al., 2014). Previous reports on essential oils indicated that the most active essential oil compounds are terpene derivatives and organic molecules containing functional groups, while hydrocarbonsare the least active compounds (Burt, 2004; Kalemba and Kunicka, 2003). The major components of $L$. petiolata (Hook f) leaf oil were 2-ketones $(88.92 \%)$ which was obtained from mainly 2-undecanone (79.52\%). This component normally showed a moderate antibacterial activity (Reddy and Al-Rajab, 2016). Al-Shuneigat $e t$ al. (2015) reported that the anti-bacterial activity of Ruta graveolens essential oil was resulted from ketones. The antibacterial activity of $L$. petiolata (Hook f) leaf oil may be similarly correlated to its ketones content, while the minor compounds could be responsible for other synergistic properties such as $2 E, 6 Z$-farnesol, $Z$-amyl cinnamaldehyde, longifolene, $\delta$ terpineol \& dihydro-eudesmol also as reported by Burt (2004). 
Table 2: Antibacterial activities of essential oil of L. petiolata (Hook f) leaf oil and penicillin.

\begin{tabular}{|c|c|c|c|c|}
\hline \multirow[t]{2}{*}{ Bacteria } & \multicolumn{2}{|c|}{ Inhibition diameter (mm) } & \multicolumn{2}{|c|}{$\mathrm{MIC}(\boldsymbol{\mu g} / \mathbf{m L})$} \\
\hline & Essential oil & Penicillin & Essential oil & Penicillin \\
\hline \multicolumn{5}{|l|}{ Gram-positive } \\
\hline B. cereus ATCC 11778 & $11.76 \pm 2.81$ & $15.08 \pm 0.91$ & 125 & 3.91 \\
\hline B. subtilis TISTR 008 & $18.07 \pm 2.19$ & $13.75 \pm 1.22$ & 125 & 3.91 \\
\hline E. faecalis ATCC 29212 & - & $11.12 \pm 1.15$ & - & 62.50 \\
\hline S. aureus ATCC 25923 & $10.14 \pm 2.54$ & $10.08 \pm 0.29$ & 31.25 & 7.81 \\
\hline S. epidermidis ATCC 12228 & $10.25 \pm 1.67$ & $12.25 \pm 2.28$ & 125 & 15.62 \\
\hline S. agalactiae DMST 17129 & $9.68 \pm 1.39$ & $15.23 \pm 2.38$ & 500 & 15.62 \\
\hline \multicolumn{5}{|l|}{ Gram-negative } \\
\hline E. coli ATCC 25922 & $9.54 \pm 1.24$ & $10.41 \pm 1.56$ & 31.25 & 7.81 \\
\hline K. pneumoniae ATCC 700603 & - & $9.15 \pm 2.54$ & - & 500 \\
\hline P. mirabilis DMST 8212 & - & $8.42 \pm 3.12$ & - & 500 \\
\hline P. aeruginosa ATCC 27853 & - & $7.75 \pm 1.20$ & - & 125 \\
\hline S. typhi DMST 22842 & - & $11.12 \pm 1.15$ & - & 1000 \\
\hline S.typhimurium ATCC 13311 & $9.81 \pm 2.17$ & $9.55 \pm 1.10$ & 125 & 7.81 \\
\hline S. flexneri DMST 4423 & - & $7.08 \pm 2.17$ & - & 500 \\
\hline V. cholerae DMST 2873 & $9.54 \pm 1.55$ & $17.15 \pm 1.87$ & 250 & 125 \\
\hline V. parahaemolyticus DMST 21243 & $9.98 \pm 2.47$ & $11.36 \pm 1.68$ & 125 & 62.50 \\
\hline
\end{tabular}
-not detected

Normally, cell membrane is main target of essential oil components. It is extinguished resulting in ions leakage, membrane permeability, and obstruction of enzymes or proteins (Saad et al., 2013; Hyldgaard et al., 2012; Cox et al., 2000).The broad spectrum antibacterial activity of $L$. petiolata (Hook f) leaf oil against tested pathogenic bacteria was detected in Grampositive bacteria. It was noted that Gram-negative bacteria may contain higher resistance to the L. petiolata (Hook f) leaf oil than those found in Gram-positive bacteria. This result may be related to the structure of cell wall in Gram-negative bacteria which is hydrophilic and constitutes mainly of a lipo-polysaccharide inhibiting the penetration of hydrophobic oil and avoiding the accumulation of $L$. petiolata (Hook f) leaf oilin the target cell membrane (Bajpai et al., 2008).

Gram-positive bacteria were considered to be more sensitive to the L. petiolata (Hook f) leaf oil than Gram-negative bacteria (Amensour et al., 2010). Essential oil of L. petiolata (Hook f) leaves was effective against most tested bacterial pathogens included in the study. However, the susceptibility of Gram-negative bacteria may be variable due to genetic factors. Thus, the antibacterial activity of L. petiolata (Hook f) leaf oil may be differed due to the existence of some targets (Boire et al., 2013). Leaf oil of L. petiolata (Hook f) presented the great antibacterial potential toward $S$. aureus ATCC 25923 and E. coli ATCC 25922.

\section{CONCLUSIONS}

The L. petiolata (Hook f) leaf oil showed various degrees of antibacterial properties against tested pathogenic bacteria significant growth inhibiting effects on Gram-positive ( $S$. aureus) and Gram-negative bacteria (E. coli). The potential of leaf oil of $L$. petiolata (Hook $\mathrm{f}$ ) against these pathogens may suggest a scientific knowledge for the developing of this plant in the prevention and treatment of bacterial infections.

\section{ACKNOWLEDGEMENTS}

The authors thank Mae Fah Luang University for supporting instruments. We express our gratitude Mae Fah Luang University Botanical Garden, Chiang Rai, Thailand for collecting and identifying L. petiolata (Hook f) plant.

\section{Financial support and sponsorship: Nil.}

Conflict of interest: The authors declare no conflict of interest.

\section{REFERENCES}

Adams RP. Identification of essential oil components by gas chromatography/quadrupole mass spectroscopy. Allured Pub Corp, Carol Stream, IL, USA, 2001.

Al-Shuneigat JM, Al-Tarawneh IN, Al-Qudah MA, Al-Sarayreh SA, Al-Saraireh YM, Alsharafa KY. The chemical composition and the antibacterial properties of Ruta graveolens L. essential oil grown in Northern Jordan. Jordan J Biological Sci, 2015; 8:139-143.

Amensour M, Sendra E, Pérez-Alvarez JA, Skali-Senhaji N, Abrini J, Fernández-López J. Antioxidant activity and chemical content of methanol and ethanol extracts from leaves of rockrose (C. ladaniferus). Plants Foods Hum Nutr, 2010; 65:170-178.

Bajpai VK, Rahman A, Sun CK. Chemical composition and inhibitory parameters of essential oil and extracts of Nandina domestica Thunb. to control food-borne pathogenic and spoilage bacteria. Int J Food Microbiol, 2008; 125:117-122.

Boire NA, Riedel S, Parrish NM. Essential oils and future antibiotics: new weapons against emerging superbugs. J Anc Dis Prev Rem, 2013; 1:1-5.

Burt S. Essential oils: their antibacterial properties and potential applications in foods-a review. Int J Food Microbiol, 2004; 94:223-253.

Cox SD, Mann CM, Markham JL, Bell HC, Gustafson JE, Warmington JR, Wyllie SG. The mode of antimicrobial action of the essential oil of Melaleuca alternifolia (tea tree oil). J Applied Microbiol, 2000; 88:170-175.

Hossain MA, Harbi SR, Weli AM. Comparison of chemical constituents and antimicrobial activities of three essential oils from three different brands' clove samples collected from Gulf region. Asian Pac J Trop Dis, 2014; 4:262-268. 
Hyldgaard M, Mygind T, Meyer RL. Essential oils in food preservation: mode of action, synergies, and interactions with food matrix components. Frontiers in Microbiol, 2012; 3:1-24.

Jallali I, Zaouali Y, Missaoui I, Smeoui A. Variability of antioxidant and antibacterial effects of essential oils and acetonic extracts of two edible halophytes: Crithmum maritimum L. and Inula crithmoïdes L. Food Chem, 2014; 145:1031-1038.

Kalemba D, Kunicka A. Antibacterial and antifungal properties of essential oils. Curr Med Chem, 2003; 10:813-829.

Li W, Shi Q, Liang Q, Xie X, Huang X and Chen Y. Antibacterial activity and kinetics of Litsea cubeba oil on Escherichia coli. PLOS ONE, 2014; 9: 1-6.

Mar A, Pripdeevech P. Chemical composition and antibacterial activity of essential oil and extracts of Citharexylum spinosum flowers from Thailand. Nat Prod Commun, 2014; 9, 707-710.

Memish ZA, Venkatesh S, Shibl AM. Impact of travel on international spread of antimicrobial resistance. Int J Antimicrob Agents, 2003; 21:135-142.

Pandey AK, Mohan M, Singh P, Palni UT, Tripathi NN. Chemical composition, antibacterial and antioxidant activity of essential oil of Eupatorium adenophorum Spreng. fromEastern Uttar Pradesh, India. Food Biosci, 2014; 7:80-88.

Pulpipat N, Laohakunjit N, Kerdchoechuen O, Chatpaisarn A. Physical properties and volatile compound of Listea petiolata. Agricultural Sci J, 2011; 42:313-316.

Reddy DN, Al-Rajab AJ. Chemical composition, antibacterial and antifungal activities of Ruta graveolens L. volatile oils. Cogent Chemistry, 2016; 2:1220055.

Saad NY, Muller CD, Lobstein A. Major bioactivities and mechanism of action of essential oils and their components. Flavour Fragr J, 2013; 28:269-279.

Stefanakis MK, Touloupakis E, Anastasopoulos E, Ghanotakis D, Katerinopoulos HE, Makridis P. Antibacterial activity of essential oils from plants of the genus Origanum. Food Control, 2013; 34:539-546.
Suksamerkun W, Thongsomchitt S, Wongkrajang Y, Temsiririrkkul R, Kitphati W, Thongpraditchote S. Screening of antioxidant activity of vegetables in Thailand. JAASP, 2013; 2:254-261.

Tian J, Zeng XB, Zhang S. Regional variation in components and antioxidant and antifungal activities of Perilla frutescens essential oils in China. Ind Crop Prod, 2014; 59:69-79.

Yapar N, Erdenizmenli M, Oğuz VA, Kuruüzüm Z, Senger SS, Cakir N, Yüce A. Infectious disease consultations and antibiotic usage in a Turkish university hospital. Int J Infect Dis, 2006; 10:61-65.

Yoon WJ, Kang SC and Ham YM. Antioxidative and antiinflammatory activities of Litsea japonica leaves' Kor Soc App Bio Chem 2010; 53:27-32.

Zhang X. Traditional medicine: its importance and protection," in protecting and promoting traditional knowledge: systems, national experiences and international dimensions, part 1 , The role of traditional knowledge in healthcare and agriculture, Twarog S and Kapoor P, Eds., pp. 3-6, United Nations, New York, NY, USA, 2004

\section{How to cite this article:}

Atiphasaworn P, Monggoot S, Pripdeevech P. In vitro antibacterial activity and essential oil composition of Litsea petiolata Hook. f. leaves. J App Pharm Sci, 2017; 7 (09): 094-098. 